\title{
FAKTOR YANG BERHUBUNGAN DENGAN PERILAKU MEROKOK PADA SISWA DI SMA NEGERI 3 PANGKEP
}

\author{
Rizky Aulia $\mathbf{R}^{1}$, Muzakkir ${ }^{2}$, Alfiah $\mathrm{A}^{3}$ \\ ${ }^{1}$ STIKES Nani Hasanuddin Makassar \\ ${ }^{2}$ STIKES Nani Hasanuddin Makassar \\ ${ }^{3}$ STIKES Nani Hasanuddin Makassar
}

Alamat Korespondensi : (auliarizky331@gmail.com / 081340259256)

\begin{abstract}
ABSTRAK
Perilaku merokok merupakan perilaku yang berbahaya bagi kesehatan, tetapi masih banyak orang yang melakukannya, bahkan orang mulai merokok ketika dia masih remaja. Tujuan penelitian ini untuk mengetahui adanya hubungan antara lingkungan, sikap, pengetahuan dan stres dengan perilaku merokok pada siswa di SMA Negeri 3 Pangkep. Penelitian ini menggunakan desain cross sectional. Pengambilan sampel menggunakan teknik nonprobability sampling yaitu purposive sampling didapatkan 57 responden. Pengumpulan data dilakukan menggunakan kuesioner dan dianalisis dengan uji chi square $(p<0.05)$. Hasil analisis bivariat menunjukkan adanya hubungan antara lingkungan dengan perilaku merokok $(p=0,032)$, adanya hubungan antara sikap dengan perilaku merokok $(p=0,019)$, adanya hubungan antara pengetahuan dengan perilaku merokok $(p=$ $0,025)$, dan adanya hubungan antara stres dengan perilaku merokok $(p=0,012)$. Kesimpulan dalam penelitian ini adalah terdapat hubungan antara lingkungan, sikap, pengetahuan, dan stres dengan perilaku merokok pada siswa di SMA Negeri 3 Pangkep.
\end{abstract}

\section{Kata kunci : Lingkungan, Pengetahuan, Perilaku Merokok, Sikap, Stres}

\section{PENDAHULUAN}

World Health Organization (WHO) memprediksikan bahwa pada tahun 2020 kematian didunia mencapai $73 \%$ disebabkan oleh penyakit yang tidak menular. Tingginya insiden penyakit tidak menular disebabkan beberapa faktor salah satunya adalah merokok setiap hari (Isa, Lestari, \& Afa, 2017).

Menurut Agustina (2017) Di Indonesia, perilaku merokok mengalami peningkatan terbesar yang cenderung dimulai pada usia muda. Pada usia $10-14$ tahun, terdapat 2,0\% remaja yang merokok, $0,7 \%$ di antaranya merokok setiap hari dan $1,3 \%$ perokok kadang-kadang mengkonsumsi 10 batang rokok per hari. Proporsi penduduk menurut usia mulai merokok untuk kelompok usia muda (5 - 9 tahun) yang tertinggi adalah di Papua $(3,2 \%)$, sekitar 30 kali lebih besar dibandingkan dengan angka nasional $(0,1 \%)$ Untuk kelompok usia mulai merokok $10-14$ tahun, Sumatera Barat menduduki posisi tertinggi (13,6\%). Kondisi ini yang menyebabkan Indonesia disebut sebagai satusatunya negara di dunia dengan baby smoker atau perokok anak.

Sementara, di Sulawesi Selatan Menurut Agustina (2017) angka kejadiannya sekitar $0,8 \%$ atau 8 kali lebih besar dibandingkan dengan angka nasional. Untuk kelompok usia mulai merokok $10-14$ tahun, sekitar 10,0\%, lebih tinggi dibandingkan dengan angka nasional $(9,6 \%)$.

Berdasarkan pengambilan data tahun 2017 tentang perokok dibawah usia 18 tahun di Kota Makassar yaitu jumlah penduduk lakilaki sebanyak 53.521 orang sedangkan yang merokok 5.884 orang (10.9\%). Dan jumlah penduduk perempuan 58.743 orang sedangkan yangmerokok 50 orang $(0.08 \%)$ (Pomanto, 2018).

Peneliti telah mengambil data awal di SMA Negeri 3 Pangkep dengan jumlah keseluruhan kelas X IPA adalah 216 orang dan jumlah siswa laki-laki sebanyak 66 orang dan jumlah siswa perempuan sebanyak 150 orang (Data Tahun 2018 SMA Negeri 3 Pangkep).

Berdasarkan data tersebut, peneliti tertarik untuk melakukan penelitian dengan judul Faktor Yang Berhubungan Dengan Perilaku Merokok Pada Remaja di SMA Negeri 3 Pangkep.

\section{BAHAN DAN METODE}

Lokasi, Populasi dan Sampel

Penelitian ini dilaksanakan di SMANegeri 3 Pangkep, dimulai pada tanggal 13 sampai dengan 21 Desember 2018. Populasi pada penelitian ini berjumlah 66 responde, dan sampel dalam penelitian sebanyak 57 responden. 
1. Kriteria Inklusi

a. Siswa remaja putra kelas X di SMA Negeri 3 Pangkep yang bersedia menjadi responden.

b. Siswa remaja putra kelas $X$ di SMA Negeri 3 Pangkep yang hadir saat kuesioner dibagikan.

c. Siswa remaja putra kelas $X$ di SMA Negeri 3 Pangkep yang merokok.

d. Siswa remaja putra kelas $X$ di SMA Negeri 3 Pangkep yang telah merokok selama satu bulan.

2. Kriteria Eksklusi

a. Siswa yang tidak kooperatif.

b. Siswa yang tidak bersedia menjadi responden.

c. Siswa remaja putra yang tidak hadir pada saat penelitian

\section{Pengumpulan Data}

Pengumpulan data merupakan cara peneliti untuk mengumpulkan data dalam penelitian (Hidayat, 2014). Data yang diperoleh terbagi atas dua jenis data yaitu :

1. Data primer adalah data yang diambil dan diperoleh langsung melalui kuesioner.

2. Data sekunder adalah data yang diambil atau diperoleh dari tata usaha SMA Negeri 3 Pangkep.

\section{Pengolahan Data}

1. Editing

Editing adalah upaya untuk memeriksa kembali kebenaran data yang diperoleh atau di kumpulkan, editing dapat dilakukan pada tahap pengumpulan data atau setelah data terkumpul. (Hidayat, 2014)

2. Coding

Coding merupakan kegiatan pemberian code numeric (angka) terdapat data yang terdiri atas beberapa kategori. Pemberian kode ini sangat penting bila pengolahan data analisa data menggunakan computer. (Hidayat, 2014)

3. Entri Data

Data entri adalah kegiatan memasukkan data yang telah dikumpulkan ke dalam master table atau database computer, kemudian membuat distribusi frekuensi sederhana atau biasa juga dengan membuat table kontigensi (Hidayat, 2014).

4. Melakukan Teknik Analisis

Dalam melakukan analisis, khususnya terdapat data penelitian akan menggunakan ilmu statistik terapan yang disesuaikan dengan tujuan yang hendak dianalisis. Apabila penelitiannya deskriptif, maka akan menggunakan statistic deskriptif. (Hidayat, 2014).

\section{HASIL PENELITIAN}

1. Analisis Univariat

Tabel 1 Distribusi Frekuensi Responden Berdasarkan Kelompok Umur Di Kelas X SMA Negeri 3 Pangkep

\begin{tabular}{|l|c|c|}
\hline \multicolumn{1}{|c|}{ Umur } & $n$ & $(\%)$ \\
\hline 15 Tahun & 47 & 82,5 \\
\hline 16 Tahun & 10 & 17,5 \\
\hline Total & 57 & 100 \\
\hline
\end{tabular}

Berdasarkan tabel 1 diatas menunjukkan bahwa dari 57 responden yang diteliti, terdapat 47 responden $(82,5 \%)$ yang berada pada umur 15 tahun dan 10 responden $(17,5 \%)$ yang berada pada umur16 tahun.

2. Analisis Bivariat

Tabel 2 Hubungan Antara Variabel Lingkungan Dengan Perilaku Merokok pada Siswa Di SMA Negeri 3 Pangkep

\begin{tabular}{|c|c|c|c|c|c|c|}
\hline \multirow{2}{*}{ Lingkungan } & \multicolumn{3}{|c|}{ Perilaku Merokok } & \multicolumn{2}{c|}{ Total } \\
\cline { 2 - 5 } & \multicolumn{2}{|c|}{ Aktif } & \multicolumn{2}{c|}{ Pasif } & \multirow{2}{*}{$\%$} & $\%$ \\
\cline { 2 - 6 } & $n$ & $\%$ & $n$ & $\%$ & & \\
\hline $\begin{array}{c}\text { Kurang } \\
\text { Baik }\end{array}$ & 43 & 75,4 & 1 & 1,8 & 44 & 77,2 \\
\hline Baik & 10 & 17,5 & 3 & 5,3 & 13 & 22,8 \\
\hline Total & 53 & 93,0 & 4 & 7,0 & 57 & 100 \\
\hline \multicolumn{7}{|c|}{$\alpha=0,032$} \\
\hline$\alpha=0,05$ \\
\hline
\end{tabular}

Berdasarkan tabel 2 menunjukkan bahwa dari 57 responden yang diteliti, terdapat 44 responden $(77,2 \%)$ kurang baik dimana 43 responden $(75,4 \%)$ masuk dalam kategori perokok aktif dan 1 responden $(1,8 \%)$ masuk dalam kategori pasif. Sedangkan 13 responden $(22,8 \%)$ baik, dimana 10 responden $(17,5 \%)$ masuk kedalam kategori perokok aktif dan 3 responden $(5,3 \%)$ masuk dalam kategori perokok pasif.

Dari hasil uji statistik Chi-square maka diperoleh nilai $\rho=0,032$ dimana nilai $\rho<\alpha$ maka Ha diterima dan $\mathrm{HO}$ ditolak. Hal ini menunjukkan bahwa ada hubungan yang bermakna antara lingkungan dengan perilaku merokok pada siswa di SMA Negeri 3 Pangkep.

Tabel 3 Hubungan Antara Variabel Sikap Dengan Perilaku Merokok pada Siswa Di SMA Negeri 3 Pangkep

\begin{tabular}{|c|c|c|c|c|c|c|}
\hline \multirow{2}{*}{ Sikap } & \multicolumn{3}{|c|}{ Perilaku Merokok } & \multicolumn{2}{c|}{ Total } \\
\cline { 2 - 5 } & \multicolumn{2}{|c|}{ Aktif } & \multicolumn{2}{|c|}{ Pasif } & \multirow{2}{*}{$\%$} & \multirow{2}{*}{$\%$} \\
\cline { 2 - 6 } & $n$ & $\%$ & $n$ & $\%$ & & \\
\hline Positif & 45 & 78,9 & 1 & 1,8 & 46 & 80,7 \\
\hline Negatif & 8 & 14,0 & 3 & 5,3 & 11 & 19,3 \\
\hline Total & 53 & 93,0 & 4 & 7,0 & 57 & 100 \\
\hline \multicolumn{6}{|c|}{$\alpha=0,019$} \\
\hline & $\alpha=0,05$ \\
\hline
\end{tabular}


Berdasarkan tabel 3 menunjukkan bahwa dari 57 responden yang diteliti, terdapat 46 responden $(80,7 \%)$ positif dimana 45 responden $(78,9 \%)$ masuk dalam kategori perokok aktif dan 1 responden $(1,8 \%)$ masuk dalam kategori pasif. Sedangkan 11 responden $(19,3 \%)$ negatif, dimana 8 responden $(14,0 \%)$ masuk kedalam kategori perokok aktif dan 3 responden $(5,3 \%)$ masuk dalam kategori perokok pasif.

Dari hasil uji statistik Chi-square maka diperoleh nilai $\rho=0,019$ dimana nilai $\rho<\alpha$ maka Ha diterima dan $\mathrm{HO}$ ditolak. Hal ini menunjukkan bahwa ada hubungan yang bermakna antara lingkungan dengan perilaku merokok pada siswa di SMA Negeri 3 Pangkep.

Tabel 4 Hubungan Antara Variabel Pengetahuan Dengan Perilaku Merokok pada Siswa Di SMA Negeri 3 Pangkep

\begin{tabular}{|c|c|c|c|c|c|c|}
\hline \multirow{2}{*}{ Pengetahuan } & \multicolumn{3}{|c|}{ Perilaku Merokok } & \multicolumn{2}{c|}{ Total } \\
\cline { 2 - 6 } & \multicolumn{2}{|c|}{ Aktif } & \multicolumn{2}{|c|}{ Pasif } & \multirow{2}{*}{$\%$} \\
\cline { 2 - 6 } & $n$ & $\%$ & $n$ & $\%$ & & \\
\hline Tahu & 44 & 77,2 & 1 & 1,8 & 45 & 78,9 \\
\hline Tidak Tahu & 9 & 15,8 & 3 & 5,3 & 12 & 21,1 \\
\hline Total & 53 & 93,0 & 4 & 7,0 & 57 & 100 \\
\hline \multicolumn{5}{|c|}{$\alpha=0,025$} \\
\hline & $\alpha=0,05$ \\
\hline
\end{tabular}

Berdasarkan tabel 4 menunjukkan bahwa dari 57 responden yang diteliti, terdapat 45 responden $(78,9 \%)$ tahu dimana 44 responden $(77,2 \%)$ masuk dalam kategori perokok aktif dan 1 responden $(1,8 \%)$ masuk dalam kategori pasif. Sedangkan 12 responden $(21,1 \%)$ tidak tahu, dimana 9 responden $(15,8 \%)$ masuk kedalam kategori perokok aktif dan 3 responden $(5,3 \%)$ masuk dalam kategori perokok pasif. Dari hasil uji statistik Chisquare maka diperoleh nilai $\rho=0,025$ dimana nilai $\rho<\alpha$ maka $\mathrm{Ha}$ diterima dan $\mathrm{HO}$ ditolak. Hal ini menunjukkan bahwa ada hubungan yang bermakna antara lingkungan dengan perilaku merokok pada siswa di SMA Negeri 3 Pangkep.

Tabel 5 Hubungan Antara Variabel Stres Dengan Perilaku Merokok pada Siswa Di SMA Negeri 3 Pangkep.

\begin{tabular}{|c|c|c|c|c|c|c|}
\hline \multirow{2}{*}{ Stres } & \multicolumn{3}{|c|}{ Perilaku Merokok } & \multicolumn{2}{c|}{ Total } \\
\cline { 2 - 6 } & \multicolumn{2}{|c|}{ Aktif } & \multicolumn{2}{|c|}{ Pasif } & \multirow{2}{*}{$\%$} & $\%$ \\
\cline { 2 - 6 } & $n$ & $\%$ & $n$ & $\%$ & & \\
\hline Stres & 37 & 64,9 & 0 & 0 & 37 & 64,9 \\
\hline Tidak & 16 & 28,1 & 4 & 7,0 & 20 & 35,1 \\
Stres & 53 & 93,0 & 4 & 7,0 & 57 & 100 \\
\hline Total & $5=0,012$ \\
\hline \multicolumn{7}{|c|}{$\alpha=0,05$} \\
\hline \multicolumn{7}{|c|}{}
\end{tabular}

Berdasarkan tabel 5 menunjukkan bahwa dari 57 responden yang diteliti, terdapat 37 responden $(64,9 \%)$ stres dimana 37 responden $(64,9 \%)$ masuk dalam kategori perokok aktif dan tidak ada responden masuk dalam kategori pasif. Sedangkan 20 responden $(35,1 \%)$ tidak stres, dimana 16 responden (28,1\%) masuk kedalam kategori perokok aktif dan 4 responden $(7,0 \%)$ masuk dalam kategori perokok pasif.

Dari hasil uji statistik Chi-square maka diperoleh nilai $\rho=0,012$ dimana nilai $\rho<a$ maka Ha diterima dan $\mathrm{HO}$ ditolak. Hal ini menunjukkan bahwa ada hubungan yang bermakna antara lingkungan dengan perilaku merokok pada siswa di SMA Negeri 3 Pangkep.

\section{PEMBAHASAN}

1. Hubungan Antara Sikap dengan Perilaku Merokok Pada Siswa di SMA Negeri 3 Pangkep

Berdasarkan hasil penelitian menunjukkan bahwa dari 57 responden yang diteliti, terdapat 44 responden $(77,2 \%)$ kurang baik dimana 43 responden $(75,4 \%)$ masuk dalam kategori perokok aktif dan 1 responden (1,8\%) masuk dalam kategori pasif. Hal ini disebabkan karena banyaknya pengaruh teman sebayanya dan mereka hanya tidak ingin terlihat culun. Sedangkan 13 responden $(22,8 \%)$ baik, dimana 10 responden $(17,5 \%)$ masuk kedalam kategori perokok aktif dan 3 responden $(5,3 \%)$ masuk dalam kategori perokok pasif. Hal ini disebabkan karena mereka tidak terpengaruh oleh teman sebayanya.

Dari hasil uji statistik Chi-square maka diperoleh nilai $\rho=0,032$ dimana nilai $\rho<\alpha$ maka Ha diterima dan $\mathrm{HO}$ ditolak. Hal ini menunjukkan bahwa ada hubungan yang bermakna antara lingkungan dengan perilaku merokok pada siswa di SMA Negeri 3 Pangkep.

Penelitian ini sejalan dengan penelitian yang dilakukan oleh Riandinata (2018) tentang Hubungan Lingkungan Keluarga Dan Teman Sebaya Dengan Perilaku Merokok Pada Remaja Usia 18-22 Tahun Di Desa Gonilan Karatasura yang menyatakan bahwa terdapat hubungan antara teman sebaya dengan perilaku merokok dimana $\rho=0,001$.

Berdasarkan hasil penelitian sebelumnya dan teori yang mendukung, maka peneliti berpendapat bahwa terdapat hubungan antara lingkungan dengan perilaku merokok pada siswa di SMA 
Negeri 3 Pangkep, dimana $\rho=0,032<\alpha=$ 0,05 .

2. Hubungan Antara Sikap dengan Perilaku Merokok Pada Siswa di SMA Negeri 3 Pangkep

Berdasarkan hasil penelitian menunjukkan bahwa dari 57 responden yang diteliti, terdapat 46 responden $(80,7 \%)$ positif dimana 45 responden $(78,9 \%)$ masuk dalam kategori perokok aktif dan 1 responden $(1,8 \%)$ masuk dalam kategori pasif. Hal ini disebabkan karena responden lebih percaya diri jika responden sedang merokok dan tergantung dari keyakinan responden itu sendiri. Sedangkan 11 responden $(19,3 \%)$ negatif, dimana 8 responden $(14,0 \%)$ masuk kedalam kategori perokok aktif dan 3 responden $(5,3 \%)$ masuk dalam kategori perokok pasif. Hal ini disebabkan karena keyakinan responden itu sendiri.

Dari hasil uji statistik Chi-square maka diperoleh nilai $\rho=0,019$ dimana nilai $\rho<\alpha$ maka Ha diterima dan H0 ditolak. Hal ini menunjukkan bahwa ada hubungan yang bermakna antara lingkungan dengan perilaku merokok pada siswa di SMA Negeri 3 Pangkep.

Penelitian ini sejalan dengan penelitian yang dilakukan oleh Pangestu, Cahyo \& Kusumawati (2017) tentang Faktor yang Berhubungan Dengan Perilaku Merokok Shisha Pada Remaja Siswa SMA $X$ Di Kota Semarang yang menyatakan bahwa terdapat hubungan antara sikap responden dengan perilaku merokok dimana $\rho=0,032$.

Berdasarkan hasil penelitian sebelumnya dan teori yang mendukung maka peneliti berpendapat bahwa terdapat hubungan antara sikap dengan perilaku merokok pada siswa di SMA Negeri 3 Pangkep, dimana nilai $\rho=0,019<\alpha=$ 0,05 .

3. Hubungan Antara Sikap dengan Perilaku Merokok Pada Siswa di SMA Negeri 3 Pangkep

Berdasarkan hasil penelitian menunjukkan bahwa dari 57 responden yang diteliti, terdapat 45 responden $(78,9 \%)$ tahu dimana 44 responden $(77,2 \%)$ masuk dalam kategori perokok aktif dan 1 responden $(1,8 \%)$ masuk dalam kategori pasif. Hal ini disebabkan karena rasa penasaran responden dan rasa ingin tahu responden yang lebih banyak meskipun responden tahu apa dampaknya. Sedangkan 12 responden $(21,1 \%)$ tidak tahu, dimana 9 responden $(15,8 \%)$ masuk kedalam kategori perokok aktif dan 3 responden $(5,3 \%)$ masuk dalam kategori perokok pasif. Hal ini disebabkan karena responden tahu apa dampak bagi kesehatannya.

Dari hasil uji statistik Chi-square maka diperoleh nilai $\rho=0,025$ dimana nilai $\rho<\alpha$ maka Ha diterima dan $\mathrm{H} 0$ ditolak. Hal ini menunjukkan bahwa ada hubungan yang bermakna antara lingkungan dengan perilaku merokok pada siswa di SMA Negeri 3 Pangkep.

Penelitian ini sejalan dengan penelitian yang dilakukan oleh Nurwahidah, Dramawan \& Haris (2015) tentang Hubungan Tingkat Pengetahuan Siswa Tentang Dampak Rokok Bagi Kesehatan Dengan Perilaku Merokok Siswa Di SMA PGRI Bolo Tahun 2015 yang menyatakan bahwa terdapat hubungan antara pengetahuan responden dengan perilaku merokok dimana $\rho=0,000$.

Berdasarkan hasil penelitian sebelumnya dan teori yang mendukung maka peneliti berpendapat bahwa terdapat hubungan antara pengetahuan dengan perilaku merokok pada siswa di SMA Negeri 3 Pangkep, dimana nilai $\rho=0,025<$ $\alpha=0,05$.

4. Hubungan Antara Sikap dengan Perilaku Merokok Pada Siswa di SMA Negeri 3 Pangkep

Berdasarkan hasil penelitian menunjukkan bahwa dari 57 responden yang diteliti, terdapat 37 responden $(64,9 \%)$ stres dimana 37 responden $(64,9 \%)$ masuk dalam kategori perokok aktif dan tidak ada responden masuk dalam kategori pasif. Hal ini disebabkan karena responden berpendapat bahwa dengan dia merokok stresnya akan berkurang. Sedangkan 20 responden $(35,1 \%)$ tidak stres, dimana 16 responden $(28,1 \%)$ masuk kedalam kategori perokok aktif dan 4 responden $(7,0 \%)$ masuk dalam kategori perokok pasif. Hal ini disebabkan karena responden mulai menyadari bahwa merokok dapat menyebabkan seseorang ketergantungan.

Dari hasil uji statistik Chi-square maka diperoleh nilai $\rho=0,012$ dimana nilai $\rho<\alpha$ maka Ha diterima dan HO ditolak. Hal ini menunjukkan bahwa ada hubungan yang bermakna antara lingkungan dengan perilaku merokok pada siswa di SMA Negeri 3 Pangkep.

Penelitian ini sejalan dengan penelitian yang dilakukan oleh Trisnolerah, Joseph \& Kapantow (2016) tentang Hubungan Antara Tingkat Stres Dan Pola Asuh Orang Tua Dengan Kebiasaan 
Merokok Pada Siswa Kelas X Dan XI Di SMK Negeri 2 Manado yang menyatakan bahwa terdapat hubungan antara stres responden dengan perilaku merokok dimana $\rho=0,025$.

Berdasarkan hasil penelitian sebelumnya dan teori yang mendukung maka peneliti berpendapat bahwa terdapat hubungan antara stres dengan perilaku merokok pada siswa di SMA Negeri 3 Pangkep, dimana nilai $\rho=0,012<\alpha=$ 0,05 .

\section{KESIMPULAN}

1. Ada hubungan antara lingkungan dengan perilaku merokok pada siswa di sma negeri 3 pangkep.

2. Ada hubungan antara sikap dengan perilaku merokok pada siswa di sma negeri 3 pangkep.

\section{DAFTAR PUSTAKA}

Agustina, F. (2017). Hubungan Umur Dan Perilaku Merokok Siswa Kelas I SMP Terhadap Prestasi Belajar. CENDEKIA MEDIKA , 106-116. Hidayat, A. A. (2014). Metode Penelitian Keperawatan Dan Teknik Analisis Data. Jakarta: Salemba Medika.

Isa, L., Lestari, H., \& Afa, J. R. (2017). Hubungan Tipe Kepribadian, Peran Orang Tua Dan Saudara, Peran Teman Sebaya,Dan Peran Iklan Rokok Dengan Perilaku Merokok Pada Siswa Smp Negeri 9 Kendari Tahun 2017. JURNAL ILMIAH MAHASISWA KESEHATAN MASYARAKAT , 1-10.

Nursalam. (2016). Metodologi Penelitian IImu Keperawatan Pendekatan Praktis EDISI 3. Jakarta : Salemba Medika.

Nurwahidah., Dramawan, A., \& Haris, A. (2015). Hubungan Tingkat Pengetahuan Siswa Tentang Dampak Rokok Bagi Kesehatan Dengan Perilaku Merokok Siswa Di SMA PGRI Bolo Tahun 2015. Jurnal Kesehatan Prima, 1516-1524

Pagestu, A. W., Cahyo, K., \& Kusumawati, A. (2017). Faktor-Faktor Yang Berhubungan Dengan Perilaku Merokok Shisha Pada Siswa SMA X Di Kota Semarang. JURNAL KESEHATAN MASYARAKAT, 489-499

Pomanto, M. R. (2017). Implementasi Kawasan Tanpa Rokok Kota Makassar. 1-46

Riandinata, E. (2018). Hunbungan Lingkungan Keluarga Dan Teman Sebaya Dengan Perilaku Merokok Pada Remaja Usia 18-22 Tahun Di Desa Gonilan Kartasura. Surakarta : Universitas Muhammadiyah Surakarta

Trisnolerah., Joseph, W. B. S., \& Kapantow, N. H. (2016). Hubungan Antara Tingkat Stres Dan Pola Asuh Orang Tua Dengan Kebiasaan Merokok Pada Siswa Kelas X Dan XI Di SMK Negeri 2 Manado. PHARMACON, 114-121 